\title{
Políticas Linguísticas na cidade de Itaiópolis-SC: relações entre língua e identidade
}

Djane Antonucci Correa ${ }^{a}$

Taís Regina Güths ${ }^{b}$

\begin{abstract}
Resumo
Este artigo propõe problematizar políticas linguísticas relacionadas à manutenção do uso da língua de imigração polonesa no município de Itaiópolis - Santa Catarina, o qual contou com significava imigração dessa etnia, de modo a discutir a relação entre políticas linguísticas in vivo e in vitro (CALVET, 2007), bem como a relação que pode ser estabelecida entre lingua e identidade. Para isso, são apresentadas falas de membros da comunidade, tidos nessa pesquisa como agentes de politicas linguísticas. Ressaltamos que a maioria dos participantes da pesquisa é vinculada a algum projeto voltado à manutenção da língua e da cultura de imigração, entre os quais destacamos um projeto da Igreja Católica do município que visa a oferecer aula de língua polonesa à comunidade e ou tro projeto desenvolvido em uma escola estadual que objetiva fornecer possibilidades de os alunos entrarem em contato com a lingua e com a cultura polonesa por meio do contato com falantes nativos da Polônia. Como resultados, destacamos que foi possível perceber que as esferas de gestão in vivo e in vitro se relacionam de forma bastante marcada. Além disso, em relação à questão identitária, percebemos que esta pode ser considerada a principal força que move esses agentes de políticas linguísticas.
\end{abstract}

Palavras-chave: Identidade. Língua polonesa. Políticas linguísticas.

Recebido em 28 de dezembro de 2016 Aceito em 09 de maio de 2017

\footnotetext{
aProfessora na Universidade Estadual de Ponta Grossa no Curso de Licenciatura em Letras e no Mestrado em Linguagem, Identidade e Subjetividade. E-mail: djanecorrea@uol.com.br

bProfessora de língua portuguesa da rede estadual de ensino do Paraná e professora colaboradora no curso de Letras da Universidade Estadual de Ponta Grossa. E-mail: guths.tais@gmail.com
} 


\section{Palavras iniciais}

O multilinguismo encoberto pela frequente reiteração do mito do monolinguismo parece reavivado quando nos deparamos com o número crescente de refugiados a chegarem a nosso país e a, obviamente, frequentar nossas escolas, suscitando discussões que há muito têm sido negligenciadas.

Entendemos, com isso, que ensinar línguas, em meio a contextos cada vez mais multiculturais e multilíngues, é sempre um desafio que pede muitas reflexões. Rodeados por essa complexidade por vezes desconcertante, entendemos que é prioritário que os professores, mas não só eles, estejam constantemente refletindo sobre os pressupostos que movem suas práticas em relação à língua.

Assim, devemos ter em mente que, apesar do discurso oficial, o Brasil é um país multilíngue. Considerando esses contextos em que, segundo Signorini (2013, p. 75), é flagrante a "heterogeneidade etnocultural, sociolinguística, sócio-histórica e socioeconômica", buscamos problematizar neste artigo políticas linguísticas de manutenção da língua polonesa no município de Itaiópolis, Santa Catarina. Dessa forma, nosso foco recai nos modos como a língua polonesa é pensada por agentes de políticas linguísticas (RAJAGOPALAN, 2013) nessa cidade.

Itaiópolis recebeu imigrantes majoritariamente poloneses, assim marcas culturais dessa etnia, como trajes, danças, festas, construções, comidas e expressões, fazem parte do cenário cultural do município. Além disso, essa aparente valorização da cultura polonesa fica mais explícita quando consideramos que a cidade, pela lei $\mathrm{n}^{\mathrm{o}} 12.654$, de 18 de setembro de 2003, foi reconhecida como Capital Catarinense de Cultura Polonesa.

Tendo esse cenário em vista, este artigo, desdobramento de um projeto de mestrado já concluído, buscará, por meio das falas de participantes de dois projetos voltados à língua e à cultura polonesa, problematizar a relação entre políticas linguísticas in vivo e in vitro (CALVET, 2007) neste espaço de pesquisa, bem como a relação que pode ser estabelecida entre língua e identidade.

Para dar conta desse objetivo, primeiramente discutiremos conceitos fundamentais para este estudo, como política linguística, suas esferas de gestão e seus agentes, bem como a relação entre língua e identidade; na sequência, adentraremos 
a pesquisa de campo, por meio de uma contextualização do espaço, dos métodos de coleta e dos participantes; então, proporemos reflexões sobre a relação entre as esferas de gestão e sobre a questão identitária; por fim, apresentaremos algumas considerações finais.

\title{
2. Alinhando conceitos: revisitando o conceito de política linguística
}

Em se tratando do que seria política linguística, partimos das afirmações de Rajagopalan, segundo o qual ainda há muita confusão e indefinição sobre o que significa esse termo.

\begin{abstract}
Muitas vezes, [...] quando as pessoas se referem à política linguística, elas querem dizer algo como 'militância linguística' em prol de línguas na beira de extinção, línguas ou variedades que são objetos de discriminação ou descaso etc., [...] a militância faz parte daquilo que chamamos de política linguística; mas é importante frisar que ela faz apenas uma pequena parte, ainda que vital. O campo de política linguística encobre muito mais do que a militância linguística. (RAJAGOPALAN 2013, p. 19)
\end{abstract}

Já para Calvet (2007), um dos autores que discute política linguística para além da militância, o poder político sempre privilegiou essa ou aquela língua, escolhendo governar o Estado numa língua ou mesmo impor à maioria a língua de uma minoria.

A opção de um governo por determinada língua é um dos principais fatores para a construção de um sentimento nacional, considerando que, para Anderson (2008, p. 204), a nação está relacionada a um sentimento de filiação entre os membros dessa comunidade, de modo que, "[...] desde o começo, a nação foi concebida na língua, e não no sangue, [...] as pessoas podem ser 'convidadas a entrar' na comunidade imaginada".

Ressaltamos que há duas formas de gestão de políticas linguísticas, a gestão in vivo e a in vitro (CALVET, 2007). A primeira delas "refere-se ao modo como as pessoas resolvem os problemas de comunicação com que se confrontam cotidianamente" (CALVET, 2007, p. 69); a gestão in vitro referese ao tratamento desses problemas pelo poder oficial. 
Maher, tratando de alguns mitos que circundam o campo das políticas linguísticas, afirma que muitos ainda acreditam que as políticas linguísticas seriam sempre explícitas e partiriam do governo. A autora esclarece que

políticas linguísticas podem também ser arquitetadas e colocadas em ação localmente: uma escola ou uma família, por exemplo, podem estabelecer - e colocar em prática planos para alterar uma certa situação (sócio) linguística [...]. (MAHER, 2013, p. 120)

Dessa forma, quando se considera que políticas linguísticas não se restringem às decisões do Estado, há uma gama muito maior de ações que podem ser consideradas. É importante ressaltar que as escolhas que acontecem na esfera in vivo não podem ser desconsideradas, uma vez que muitas delas ocupam um espaço relevante no pensar sobre a língua. Altenhofen (2013, p. 103) lista alguns exemplos:

a proibição de uso de uma língua no currículo escolar, a decisão da carga horária para o ensino de línguas adicionais no currículo, a decisão sobre as línguas estrangeiras solicitadas nas provas de vestibular, a decisão de um sacerdote para realizar um sermão na língua da comunidade, a decisão de um estabelecimento comercial para contratar empregados que 'falem determinada língua' [...], a opção na denominação de uma entidade ou estabelecimento comercial [...]. (ALTENHOFEN, 2013, p. 103)

Dessa forma, o papel do agente de políticas linguísticas é fundamental. Para Rajagopalan (2013, p. 36), o agente é aquele que se distingue pela sua vontade de se autoafirmar e marcar o seu posicionamento, "[...] ele é um sujeito que conseguiu furar o cerco da estrutura que o esmagava e tolhia a sua autonomia e desejo e direito de agir".

Maher, ao tratar dos mitos em relação às políticas linguísticas, explica que um deles é acreditar que essas sempre buscam soluções para "problemas linguísticos". Isso é um mito porque, segundo a autora,

o que se almeja, quase sempre, é a manipulação das identidades dos falantes de uma dada língua, seja no sentido de enaltecê-las ou de denegri-las. Há uma relação profunda, estreita e visceral entre políticas linguísticas e políticas de identidade. Decorre daí que o estabelecimento de políticas linguísticas não são nunca processos neutros, apolíticos ou isentos de conflito [...]. (MAHER, 2013, p. 120-121) 
A partir disso, temos clareza de que, por meio de políticas linguísticas, muitas vezes busca-se manipular a identidade dos falantes com determinado objetivo, assim como ocorreu recorrentemente nas políticas linguísticas de nosso país, como com a nacionalização de ensino.

\section{Adentrando a pesquisa de campo: breve contextualização}

Esta pesquisa foi realizada nos anos de 2013 e 2014 e contou com o acompanhamento de dois projetos que se relacionam à manutenção da cultura de imigração, já que o objetivo principal dizia respeito a problematizar relações entre língua e identidade a partir de políticas linguísticas empregadas no município. São eles:

O primeiro é um curso de língua polonesa da Igreja Católica do município, a Igreja Santo Estanislau. O curso contava com três turmas com seis aulas mensais. É importante ressaltar que a igreja disponibiliza o espaço para que as aulas aconteçam, auxiliando a professora no que é necessário, como na montagem da biblioteca formada por livros em polonês. Por outro lado, os alunos participam ativamente das missas da igreja, seja por meio de leituras ou de cantos em polonês.

O segundo é um projeto de intercâmbio que é realizado em uma escola estadual. Apesar de o nome poder passar a ideia de deslocamento físico dos alunos, trata-se de uma parceria entre a escola polonesa Liceum Ogólnokształcąceim Marii Skłodowskiej-Curie e uma escola estadual brasileira, por meio da qual os alunos de ambas interagem utilizando videoconferências, redes sociais e blogs, desenvolvendo projetos que visam à troca de conhecimentos referentes aos dois países. Apesar de o foco não ser o aprendizado da língua polonesa, o projeto se configura como uma possibilidade de os alunos entrarem em contato com a língua e com a cultura polonesa.

O acompanhamento se deu por observações in loco seguidas de oito entrevistas contemplando professores e alunos dos projetos, além de membros da comunidade, uma vez que a proposta é discutir a relação entre as diferentes esferas de gestão entendendo que todos eles podem ser considerados agentes de políticas linguísticas. 


\section{Entre o in vivo e o in vitro}

Para iniciar a discussão sobre a relação entre as esferas de gestão, salientamos que compreendemos a igreja como um espaço em que a comunidade pode ajudar a construir os rumos do uso da língua polonesa da comunidade de Itaiópolis. A escola, à primeira vista, foi compreendida como um espaço regido pelo poder político, seja em âmbito federal ou estadual, no qual se poderia perceber como a escola se preocupa com a questão das línguas de imigração a partir das concepções das esferas do poder público.

Partimos do pressuposto de que a escola buscava manter essa cultura, como a língua polonesa da comunidade, considerando que muitos alunos são dessa ascendência, de modo a ser a proponente do projeto de intercâmbio. Porém, o que ficou bastante evidente é que, na verdade, o que ocorre são tentativas da própria comunidade de ocupar um espaço em relação ao qual a escola não demonstra tanto interesse. Prova disso é uma brecha encontrada para realizar um projeto como o de intercâmbio, que é vinculado a ações da Igreja, pois há alunos que precisam de espaços como esses até para refletirem sobre quem eles são em meio a essa complexidade que existe em uma comunidade multicultural.

Voltando a tratar da relação entre igreja e escola, salientamos que o projeto desenvolvido na escola tem como idealizadora a professora de polonês que leciona no projeto de ensino de línguas da igreja. Assim, podemos perceber que, apesar de estarmos em um ambiente que é mantido pelo poder público, ou seja, onde são postas em práticas as políticas linguísticas de Estado, a esfera in vivo consegue desempenhar um papel relevante. Estamos em um espaço entre o in vivo e o in vitro, pois esses se relacionam de maneira bastante visível.

É importante refletirmos sobre esse espaço ocupado por membros da comunidade vinculados à instituição religiosa, uma vez que, como vimos, eles também são responsáveis por arquitetar políticas linguísticas. Sobre isso, ressaltamos que

${ }^{1}$ Denominamos de P1P8 os oito participantes das entrevistas. perguntamos à professora de polonês $\left(\mathrm{P} 1^{1}\right)$ : “A instituição religiosa se vê responsável pela manutenção do uso da língua 
polonesa? Se sim, de que forma? Qual a relação dessa língua com a religião católica nesse contexto?" Para ela,

A Polônia é um país muito católico e nas paróquias polonesas no exterior a igreja cuida dessa parte. Em Itaiópolis, apesar de funcionar lá a associação que promove a cultura polonesa, haver escolas públicas frequentadas por descendentes, ter a casa da cultura etc., ninguém se preocupa com a língua, o que representa um problema geral no Brasil a respeito do idioma polonês, e que obviamente me deixa muito triste. Estou grata que pelo menos a igreja católica fornece ao povo um pouco da língua. (P1. Entrevista realizada em maio de 2014)

Como pode ser visto no fragmento acima, a participante afirma algo que vai ao encontro do entendimento de que estamos cercados pelo mito do monolinguismo (CAVALCANTI, 1999), criado por ações violentas do Estado, como por meio da nacionalização do ensino. Assim, o simples fato de estarmos no Brasil bastaria para justificar um currículo monolíngue que não atende ao contexto a que se destina. Dessa forma, mesmo que haja descendentes de poloneses em um número expressivo, não há preocupação por parte das escolas em relação ao ensino de língua polonesa.

Assim, nesse contexto específico, a igreja assumiu a tarefa de não fechar os olhos ao uso das línguas de imigração que é negligenciado por outras instâncias, o que pode ter como motivo o fato de a igreja buscar, por meio dessas ações, manter um vínculo com os descendentes de poloneses, tendo em vista o público que frequenta a igreja. Contudo, o número de pessoas atingidas pelo projeto acaba por ser muito pequeno haja vista o número de descendentes de poloneses, os quais formam um grupo heterogêneo.

Essa percepção nos lembra das conclusões de Altenhofen (2013), que afirma que passamos de um estágio em que era possível o silenciamento das línguas minoritárias por meio de leis proibitivas para um estágio de tolerância relativa, até chegarmos a ações concretas de reconhecimento de línguas. Porém, apesar disso, segundo ele, não superamos os estágios de indiferença, omissão, antipatia e discriminação, ainda persistindo as dificuldades de manutenção da diversidade linguística.

Conforme já apontamos, o projeto de intercâmbio idealizado pela igreja e apenas recebido pela escola - o que não 
podemos deixar de ver com bons olhos, porque é indispensável que haja essa abertura para que o projeto se concretize não gera gastos para o estado, uma vez que é coordenado voluntariamente. Ao estado, por meio da escola, só coube acolher o projeto. Contudo, devemos esclarecer que há algumas dificuldades nesse processo na opinião da coordenadora do projeto. Segundo ela,

Os alunos receberam muito bem o projeto, porém acredito que alguns desistiram devido à cobrança de entrega dos trabalhos. Outro fator é a falta de colaboração de alguns professores com a saída de alunos de suas aulas, já que os encontros são no período em que estes encontram-se na escola, muitos sentiam-se prejudicados e optaram em sair do projeto.

A falta de motivação dos professores e direção para a participação e continuidade dos alunos no projeto. (P4. Entrevista realizada em maio de 2014).

Desse modo, entendemos que as ações de agentes de políticas linguísticas ${ }^{2}$ in vivo encontram dificuldades de desenvolvimento dentro da esfera regida pelas políticas in vitro, tendo em vista que "nenhuma política linguística é destinada a agradar gregos e troianos. Ao mesmo tempo em que agrada uns, ela também vai contra os interesses de outros". (RAJAGOPALAN, 2013, p. 38).

Devemos nos lembrar de que o agente de política linguística busca intervir numa realidade linguística, a qual "não é uma questão de um fato consumado ou consensuado, mas apenas percebido." (RAJAGOPALAN, 2013, p. 39). Dessa forma, vemos que são essas diferentes percepções sobre a realidade linguística que, muitas vezes, acabam por dificultar projetos relacionados a situações de multilinguismo, ainda mais se considerarmos que, segundo Cavalcanti (1999, p. 397), a política linguística de monolinguismo "é uma questão naturalizada, tornada natural".

${ }^{2}$ Uma ressalva a ser feita é que aqueles que vão de encontro a políticas linguísticas como essa também devem ser vistos como agentes, uma vez que realizam um agenciamento, porém em outra direção.
Em nosso contexto de pesquisa, ações de membros da comunidade são imprescindíveis na realização de projetos voltados à questão polonesa. Assim, a fim de discutir a relação entre a esfera in vivo e in vitro, trazemos também outros dois participantes não vinculados a esses projetos, porém membros da comunidade e descendentes de poloneses, uma delas é 
professora aposentada de 73 anos de idade (P7) e o outro é professor de história (P8).

Primeiramente, questionamos sobre qual é a relação deles com a língua polonesa. Segundo P7,

Desde a minha infância, até os 6 anos aproximadamente, falávamos em casa só o idioma polonês, língua dos nossos antepassados, com meus pais, avós, tios, irmãos, conhecidos, vizinhos, como também a língua portuguesa era falada normalmente. Porém, aprendi melhor o português apenas na escola a partir dos 6 anos. (P7. Entrevista realizada em junho de 2014).

Em razão da idade, podemos concluir que essa participante enfrentou o período da nacionalização de ensino promovida por Getúlio Vargas, passando pela proibição do uso da sua língua de imigração. Assim, ela vê a língua polonesa como a língua dos antepassados, a língua aprendida em casa na infância. Por isso, ela afirma acreditar que

na infância há a facilidade natural de aprender outro idioma, do qual não se esquece durante a vida, como é o meu caso, estando hoje com 73 anos, porém sinto-me responsável por transmitir o conhecimento que adquiri nestes anos. Vejo com satisfação e orgulho a oportunidade de colaborar com a entrevista. (P7. Entrevista realizada em junho de 2014, grifos nossos).

P7 se vê como responsável por passar esse conhecimento para outros que se interessem. Essa participante sempre se mostrou muito aberta a participar da construção da pesquisa, fornecendo-nos muitos esclarecimentos e dividindo conosco a alegria que é, para ela, ver pessoas interessadas em discutir o futuro da língua polonesa na cidade.

Voltando à questão da relação com a língua polonesa, P8 responde de forma semelhante, dizendo:

Todos os meus antepassados familiares tanto materno quanto paterno são descendentes de poloneses, que só falavam e se comunicavam na língua polonesa. Eu mesmo quando criança só me comunicava em polonês com meus pais e minha irmã mais velha. Quando comecei a frequentar a escola, tive dificuldade na comunicação com meus colegas. Com o passar do tempo, aprendi o português e a partir desse momento só passei a me comunicar em português na escola e também em casa com os pais e irmãos. Isso fez com que eu não mais praticasse o polonês ficando um pouco no esquecimento. (P8. Entrevista realizada em junho de 2014). 
P8 tem apenas 35 anos, o que indica que ele não passou pelo período da nacionalização do ensino do Estado Novo. Contudo, o que ele relata é muito próximo do que afirmou a outra participante, uma vez que também aprendeu o português somente na escola. Uma diferença entre os relatos é que ela continuou fazendo uso da língua polonesa em casa, enquanto que ele estendeu o uso da língua portuguesa para além da escola, o que tornou o uso do polonês mais raro.

Nesse sentido é que Altenhofen pede não só que consideremos a relevância do Estado na definição de políticas linguísticas, mas também que levemos em conta as escolhas das instâncias menores que o Estado como a escola, a família e a igreja, pois

estas constituem propriamente as instâncias de aplicação das 'escolhas governamentais' e funcionam, por isso, como uma espécie de tentáculo e distribuidor de tendências mais gerais. Por exemplo, no âmbito da família, quando os pais (bilíngues) decidem ensinar ou não aos seus filhos a língua minoritária não-oficial, assumem uma determinada decisão política. (ALTENHOFEN, 2004, p. 86)

Esses relatos nos mostram o papel da escola em meio às políticas de monolinguismo, chamada por Oliveira (2005) de túmulo das línguas, uma vez que foi nesse espaço que o Estado buscou agir para garantir o sentimento de identidade nacional fixo relacionado ao uso da língua portuguesa. Essa associação feita por Oliveira (2005) nos lembra uma fala de um senhor com o qual conversamos informalmente. Conforme registro do diário de campo:

Passei em um antigo moinho no bairro de Alto Paraguaçu e resolvi parar para conhecer. Lá estava um senhor,[...] Ele me contou que, quando criança, falava alemão, mas, segundo suas palavras, 'Aí veio a escola e derrubou tudo'. Explicou que na escola era obrigado a falar português, só restando da língua alemã para ele hoje alguns cantos e orações. (Diário de campo, 8 de fevereiro de 2014)

Apesar de esse senhor ser descendente de alemães, ele nos fornece outros subsídios de como a escola teve um papel determinante no apagamento das línguas de imigração. Contudo, essa situação ainda não foi superada.

Tal é a situação encontrada até hoje no tratamento dado [ignorar a existência de uma língua], de modo geral, ao 
bilinguismo [...]. Enquanto a legislação e as instituições de ensino de línguas estrangeiras evocam as exigências do conhecimento de mais de uma língua, como requisito do mercado de trabalho e do contexto internacional, de outro lado se negligencia ou minimiza, paradoxalmente, o valor do bilinguismo societal. Se, de um lado, a competência multilíngue constitui-se em meta que dificilmente a escola brasileira atinge, de outro encontra-se à disposição da escola e da sociedade - como 'uma espécie de minério a céu aberto' do ensino de línguas, não é reconhecido e aplaudido na mesma medida, como um ideal a ser preservado e fomentado, tendo em vista os inúmeros benefícios do bilinguismo [...]. (OLIVEIRA; ALTENHOFEN, 2011, p. 190)

Vemos, pelo fato de não haver o ensino de língua de imigração nas escolas da cidade, que esse "minério a céu aberto" ainda hoje não é aproveitado em um ensino de línguas que possa fazer sentido para os alunos, considerando que muitos convivem com resquícios do uso de polonês da comunidade, principalmente falado pelos mais velhos. Essa realidade vai de encontro com o que prevê o artigo 23 da Declaração Universal dos Direitos Linguísticos, ao tratar de educação:

1. O ensino deve contribuir para fomentar a capacidade de auto-expressão linguística e cultural da comunidade linguística do território onde é ministrado.

2. O ensino deve contribuir para a manutenção e o desenvolvimento da língua falada pela comunidade linguística do território onde é ministrado.

3. O ensino deve estar sempre ao serviço da diversidade linguística e cultural, e das relações harmoniosas entre as diferentes comunidades linguísticas do mundo inteiro.

4. No quadro dos princípios anteriores, todos têm direito a aprender qualquer língua. (in: OLIVEIRA, 2003, p. 33)

Vemos, pelo que traz a Declaração, que a realidade encontrada está longe do que é visto como ideal no que se refere à educação voltada para os direitos linguísticos. Não há ações que partem da escola na busca de contribuir para a manutenção da língua falada pela comunidade linguística e, devido aos mais variados fatores, nem todos têm o direito a aprender qualquer língua, nem mesmo a língua da comunidade, considerando que a esfera in vitro não realiza ações nesse sentido. Contudo, a problemática vai além de oferecer ou não ensino de línguas de imigração, pois devemos notar que, de acordo com a professora aposentada, 
Sobre a questão do ensino, acrescento que, quando estava na direção de uma escola, até foi pensado em se oferecer aulas de polonês, mas os alunos não demonstraram interesse. (P7. Entrevista realizada em junho de 2014)

Esse dado será relevante quando nos debruçarmos, na próxima seção, na questão identitária relacionada à língua polonesa. Contudo, desde já, podemos ver indícios de que muitos não veem/viam interesse em manter o uso da língua polonesa. Ainda sobre essa questão do ensino, P8 afirma que

Em Itaiópolis, houve um certo atraso em relação à preservação da cultura polonesa devido aos impasses políticos. Não só a cultura polonesa, mas a ucraniana e a alemã também sofreram com esse impasse político, etnias que são predominantes no município de Itaiópolis. Com políticas públicas que apoiassem as culturas através de verbas para associações e grupos de danças, com certeza teríamos em Itaiópolis uma maior valorização para ou das Culturas.

Outra questão é que as escolas deveriam ter na grade escolar os idiomas dessas culturas em Itaiópolis, principalmente onde residem os grupos dessas etnias, como, em Paraguaçu, a língua polonesa e, em Iracema, a língua ucraniana, duas comunidades consideradas núcleos das duas etnias. (P8. Entrevista realizada em junho de 2014)

Esse trecho foi extraído da parte da entrevista em que os participantes traziam outras questões que julgaram importantes. Dessa forma, podemos ver que o participante traz por conta própria a questão política em relação à manutenção das práticas culturais polonesas, afirmando que esse descaso por parte do governo causa um atraso na busca pela manutenção. Assim, vemos que, apesar de o governo não agir, como por meio das leis linguísticas, contra o uso das línguas de imigração e contra as manifestações culturais desses grupos, o Estado tem um papel bastante relevante, pois, se houvesse uma política de Estado voltada a essa questão, haveria maior facilidade de as políticas linguísticas in vivo obterem sucesso. Porém, como aponta Altenhofen:

O trabalho no âmbito da política linguística em defesa da educação bilíngue e dos direitos linguísticos das comunidades indígenas foi fundamental para os avanços conquistados. Resta, no entanto, alargar essa perspectiva para o terreno das línguas de imigrantes, que sequer são mencionadas na legislação vigente, não obstante a sua 
representatividade em amplas áreas do sul do Brasil [...]. (ALTENHOFEN, 2004, p. 84)

Ao estudar a história das políticas linguísticas voltadas à imigração polonesa, é possível perceber que os imigrantes sempre buscaram manter escolas e igrejas, de modo que estas sempre estiveram relacionadas ao ensino de língua polonesa.

A presença do padre polonês era essencial na manutenção das tradições e dos costumes, i.e., da fé polonesa. Sua presença, como líder natural desse grupo primário, era essencial na preservação da língua polonesa e da polonidade entre os colonos. (WACHOWICZ, 1981, p. 107)

Fazendo um paralelo com o que ocorre atualmente na cidade de Itaiópolis, é possível perceber que a igreja continua desempenhando esse papel, até mesmo em outros espaços, como é o caso da escola em que é desenvolvido o projeto.

A constatação de que até hoje o Estado não demonstra interesse no ensino das línguas de imigração em áreas que receberam imigrantes nos leva a uma fala de Rodycz (2011), segundo a qual os imigrantes perceberam que deveriam construir a vida por si próprios. Da mesma forma, estes perceberam que a responsabilidade pela manutenção do uso da língua e das práticas culturais polonesas deveria nascer da própria comunidade, ou seja, de políticas in vivo, mas que fossem além, que também utilizassem o espaço não utilizado pela esfera in vitro.

Por outro lado, é preciso salientar que a Declaração já mencionada prevê, entre os direitos individuais inalienáveis, o direito a ser reconhecido como membro de uma comunidade linguística, o direito ao uso da língua em privado e em público, o direito a relacionar-se e associar-se com outros membros da comunidade linguística de origem e o direito a manter e desenvolver a própria cultura (OLIVEIRA, 2003).

Apesar de haver um documento prevendo isso, este não opera como uma lei, e, mesmo que fosse, "não se deve criar a ilusão de que [as leis linguísticas] funcionam como uma fórmula mágica que por si só já garante a manutenção e sobrevivência de uma língua" (ALTENHOFEN, 2013, p. 112). Nem devemos entender que o fato de haver uma lei proibindo o uso de uma língua deve ser visto como algo que garanta o 
apagamento dessa língua, já que, como mostra Rajagopalan (2005), é possível adotar uma postura de resistência consciente e consequente, como o projeto de intercâmbio.

Porém, pudemos notar que garantir o que orienta a Declaração não é uma tarefa fácil, pois, como aponta P7, a manutenção da língua passa até mesmo pela questão da autoestima, uma vez que, em uma época, falar polonês era sinônimo de falar palavrão.

Ressaltamos que, de acordo com Altenhofen (2004), boa parte do êxito de ações motivadas por políticas linguísticas no sentido de promover os direitos linguísticos das minorias linguísticas depende da compreensão do que motiva microdecisões de cunho político empregadas por membros dessas comunidades. Isso passa por compreender "valores, ideologias, mitos, 'ressentimentos', concepções e preconceitos linguísticos presentes na interação diária entre os grupos sociais e os falantes das diversas línguas e variedades em contato" (ALTENHOFEN, 2004, p. 85-86). Por isso, na próxima seção, a fim de entender o que pode motivar uma política linguística in vivo de busca da manutenção ou do apagamento das línguas, discutiremos a questão identitária, que acreditamos ser a principal força que move esses agentes de políticas linguísticas.

\section{A questão identitária: "Nossa identidade cultural"}

Primeiramente, salientamos que muitos dos alunos que participam do curso de línguas e do projeto de intercâmbio são descendentes de poloneses. Tendo em vista o modo como o projeto é desenvolvido, podemos perceber que eles têm a possibilidade de estreitar relações com membros desse país. Assim, é inegável que há uma motivação derivada da questão identitária. Contudo, essa questão não é tão simples e nem essa relação entre ser descendente e querer marcar isso pode ser vista de maneira tão direta.

Para discutir isso, iniciamos com uma fala de P1. Segundo ela,

A comunidade polonesa em Itaiópolis é grande, mas desleixada - Por enquanto nenhuma instituição pública demonstrou interesse em preservar a língua. Como demonstra a história, a igreja católica é a instituição (às vezes, 
a única) que vê essas necessidades e, além da fé, preserva a cultura. Foi justamente assim em Alto Paraguaçu. (P1. Entrevista realizada em maio de 2014).

Vemos que, na opinião de $\mathrm{P} 1$, a responsabilidade em relação à manutenção da língua é assumida pela gestão in vivo, pois as instituições públicas não realizam ações voltadas à manutenção da língua polonesa. Além disso, P1 caracteriza a comunidade como desleixada, uma vez que não são todas as pessoas da comunidade polonesa que trabalham em prol dessa manutenção, de modo que a igreja busca desempenhar esse papel. Contudo, conforme veremos, pode haver razões bastante fortes para que muitos membros não busquem deixar explícita essa relação com a cultura polonesa.

Ainda nesse mesmo sentido, P1, ao responder como é vista a importância da língua polonesa nesse contexto, afirma que

A língua polonesa é importante principalmente nas comunidades polonesas, mas infelizmente menosprezada pelos próprios descendentes; 30 alunos, sendo que 10 pessoas são do Rio da Prata, é pouco - temos que lembrar que Itaiópolis é considerada a capital da cultura polonesa no estado de Santa Catarina. São poucas pessoas que veem a necessidade de dominar a língua polonesa e aprofundar seu conhecimento da cultura da sua origem. (P1. Entrevista realizada em maio de 2014).

Nessa afirmação, vemos de forma bastante clara o que a resposta anterior a essa parecia sugerir: muitos descendentes não entendem ser necessário manter esse vínculo com as questões polonesas. Então, tendo em vista todo o contexto que remete à cultura polonesa nessa região, questionamo-nos sobre qual(is) seria(m) a(s) causa(s) para isso.

Um possível caminho para entendermos essa questão começou a ser trilhado em nossa primeira conversa com o padre da comunidade, P2, ainda antes de iniciarmos as observações. Conforme registro no diário de campo,

Quando discutíamos a importância que a comunidade dá a língua polonesa, ele me disse que muitos acabam por não falar o polonês por se sentirem inferiores dessa forma, mas que ele sempre diz para eles não terem vergonha do que são. (Diário de campo, 20 de julho de 2013, grifos nossos).

Essa questão de "terem vergonha de ser quem são" e esse suposto sentimento de inferioridade também foi algo 
que pudemos notar em algumas entrevistas. Perguntamos a todos os participantes: "Qual a visão que os descendentes de poloneses têm em relação à língua polonesa e a cultura polonesa? E qual a visão que você acredita que as demais pessoas têm em relação a isso? De que forma você percebe isso e avalia essa postura?". Essa pergunta foi pensada justamente por termos notado, nas conversas informais e nas observações, que essa questão é bastante pertinente para entendermos o modo como a língua e a identidade são pensadas no contexto da pesquisa.

Em resposta a essa questão, P8 diz que

Vejo que os descendentes de poloneses em Itaiópolis têm uma certa timidez em falar e manifestar os costumes e a língua polonesa; A visão que os descendentes têm é uma certa decadência, assim num futuro próximo não haverá mais manifestações em Itaiópolis. As demais pessoas veem a cultura e a língua polonesa como algo arcaico, velho e sem nenhuma utilidade para o município. Isso percebe-se na rejeição e nos comentários desagradáveis, principalmente pelos mais jovens de Itaiópolis. Esse tipo de postura faz com que a cultura Polonesa seja prejudicada cada vez mais. (P8. Entrevista realizada em junho de 2014, grifos nossos).

Podemos perceber, por essa resposta, que a questão da "vergonha" de que falou P2 também é relatada por P8. Ele fala de comentários desagradáveis que são feitos em relação à cultura e à língua polonesa. Isso faz com que muitos não busquem demonstrar sua identificação com essa cultura ou mesmo que não se identifiquem, principalmente os mais jovens que, muito provavelmente, não têm a mesma relação com a língua do que seus pais e/ou avós, apesar de haver, nessa geração mais nova, aqueles que buscam o aprendizado da língua. Vemos também que esses comentários pejorativos, seja em relação à língua, à cultura ou ao próprio grupo tomado como homogêneo, fazem com que haja reconfigurações no modo como os descendentes de poloneses se relacionam com a língua e com a cultura de imigração. Assim, vemos o papel da alteridade na construção da identidade, uma vez que, por meio do outro e também do que o outro afirma performativamente sobre mim, é que a minha identidade se altera, podendo haver, nesse caso, uma negação de uma possível identificação com a questão polonesa. 
A questão da criação de estereótipos vinculados aos poloneses está presente na literatura sobre a imigração polonesa. Assim podemos entender melhor qual a possível origem dessa visão negativa dos não poloneses sobre os poloneses. De acordo com Wachowicz:

A agricultura de subsistência, em regime de pequena propriedade, caracterizou pois o imigrante polonês no Brasil [...]. Por isso, o termo polaco, ou polonês, passou a ser um termo que se identificava de imediato, na sociedade local, com a agricultura. [...] Ser de origem polaca era admitir ipso facto que se pertencia a uma camada mais baixa da sociedade. (Wachowicz, 1981, p. 141, grifos do autor)

Para esse autor, o polaco foi tido sempre como alguém com baixo nível de instrução, o que fez com que muitos sentissem vergonha, levando "muitos indivíduos de ascendência polonesa a rejeitar sua origem étnica." (WACHOWICZ, 1981, p. 141). A partir disso, o mesmo autor conclui que

os estereótipos, como polaco sem bandeira, polaco burro, polaco e colarinho não se [en]quadram, polaco burro é pleonasmo, levaram alguns descendentes de poloneses a adquirirem um complexo de inferioridade, em relação à sua origem étnica. (WACHOWICZ, 1981, p. 142)

Para problematizar mais essa questão, devemos lembrar que, de acordo com a discussão da Altenhofen e Margotti (2011, p. 304), a língua portuguesa em uma comunidade de imigração poderá apresentar traços característicos no nível fonéticofonológico. Além disso, "muitos dos traços [...] apresentam uma conotação social fortemente estigmatizada [...] que leva muitos pais a abandonar a língua de imigração", nem sempre de forma a significar a perda do sotaque característico.

Essa estigmatização pôde ser percebida por esta pesquisa. Desde o início, em conversas informais, foi-nos relatado que havia muito preconceito em relação ao modo polaco de se usar a língua portuguesa. Nesse sentido, anotamos em diário de campo a nossa conversa com a diretora de uma escola na comunidade polonesa.

Ela me disse que naquela escola não há tanto esse problema, pois muitos alunos descendem de poloneses e são do interior do município, e, portanto, têm como comum o fato de falaram um "r"estigmatizado. Contudo, segundo ela, os maiores problemas estão quando esses alunos vão estudar no 
centro da cidade (na escola em que realizaremos a pesquisa), pois lá enfrentam preconceito pelo modo como falam, o que, na opinião dela, dificulta a manutenção da língua polonesa. (Diário de campo, 20 de julho de 2013, grifos nossos).

Exatamente a mesma questão apareceu nas observações das aulas de polonês, porém de uma forma que nos chamou ainda mais a atenção, uma vez que alguns alunos alegavam ter dificuldade para pronunciar esse " $r$ ". Na língua polonesa, é frequente o uso do " $r$ " tepe, por essa razão, conforme apontam inúmeros estudos sobre a temática do contato entre as línguas polonesa e portuguesa no Brasil, o português falado nesse contexto se caracteriza pelo uso - muito estigmatizado - do tepe em posição de r-forte. Essa estigmatização no português explicaria as alegadas "dificuldades" em pronunciar um som que é utilizado na variedade de língua portuguesa influenciada pelo polonês. Salientamos que, como a comunidade não é homogênea, há divergências no modo como falam o $r$, podendo ser menos ou mais marcado. De todo modo, é um modo de falar estigmatizado socialmente. Conforme anotações no diário de campo,

A professora estava explicando o alfabeto, ao chegar à letra $r$, muitos alunos tinham dificuldade para pronunciar, pois eles têm uma certa aversão a essa pronúncia. Um aluno disse: 'Aqui se a gente fala esse $r$ é defeito nosso'. (Diário de campo, 22 de março de 2014, grifos nossos).

Vemos claramente que os alunos entendem o fato de falarem esse $r$ que é estigmatizado pelos demais como algo que será julgado como um defeito deles, ou seja, as afirmações negativas sobre língua, sobre o modo como o falante usa sua língua, por extensão, são atribuídas aos sujeitos. É possível perceber que eles entendem que a estigmatização que o tepe, em posição de r-forte, sofre em português também acontecerá quando ele for pronunciado em polonês - é como se eles temessem que a estigmatização fosse transferida de uma língua para outra. Desse modo, lembramos o que Pinto (2012) nos diz sobre os consensos e as coerções criados em relação à língua e à norma, de modo que possamos pensar quais as consequências de se estabelecer uma rígida divisão entre usos "corretos" e usos "incorretos" de língua, em uma relação na qual quem faz uso das formas ditas incorretas é visto como inferior aos demais. 
Além disso, devemos retomar o mito do monolinguismo, o qual, na visão de Cavalcanti (1999, p. 387), é muito eficaz no apagamento das minorias, como as nações indígenas, as comunidades de imigrantes "e, por extensão, as maiorias tratadas como minorias, ou seja, as comunidades falantes de variedades desprestigiadas do português".

Lembramos que a Declaração Universal dos Direitos Linguísticos também trata dessa questão, considerando as discriminações contra as comunidades linguísticas inadmissíveis, sejam elas baseadas no seu grau de soberania política, na sua situação social, econômica ou qualquer outra, ou no "nível de codificação, atualização ou modernização alcançado pelas suas línguas." (OLIVEIRA, 2003, p. 29).

Nesse sentido, a partir do entendimento da construção da suposta inferioridade polonesa por meio da linguagem, podemos perceber que essa hierarquia entre as culturas resultaria da própria hierarquia social, na qual os poloneses ocupariam um lugar inferior. Além disso, há algumas discussões sobre identidade e performatividade a partir de Silva que nos ajudam a compreender essa questão:

Em geral, ao dizer algo sobre certas características identitárias de algum grupo cultural, achamos que estamos simplesmente descrevendo uma situação existente, um 'fato' do mundo social. O que esquecemos é que aquilo que dizemos faz parte de uma rede mais ampla de atos linguísticos que, em seu conjunto, contribui para definir ou reforçar a identidade que supostamente apenas estamos descrevendo. (SILVA, 2000, p. 93)

Acrescentamos que, por meio daquilo que dizemos, ou seja, por meio dos nossos atos de fala, estamos agindo sobre essas identidades de forma a contribuir para que elas sejam apagadas, reforçando características negativas que fazem com que essa identidade seja deixada de lado. Lembramos, assim, que a identidade e a diferença são construções.

Essa questão da diferença pode ser percebida na relação com a cultura alemã. Há um escrito de Wielewski de 1901, citado por Rodycz (2011), que nos mostra a necessidade da manutenção da Colônia, para ele, o progresso da Colônia era "culturalmente importante para os polono-brasileiros por representar uma barreira contra a 'germanização' da região, 
intentada pelos imigrantes alemães" (RODYCZ, 2011, p. 91). Essa questão ainda fica evidente nas falas de nossos participantes nas conversas informais, porém não nas entrevistas. Isso ocorre porque alguns, como $\mathrm{P}$, acreditam que não se deve falar sobre essa questão para não se perpetuar essa visão. Em relação a essa participante, anotamos no diário de campo:

Explicou-me que havia muita rivalidade entre o pessoal do centro e o pessoal de Alto Paraguaçu. Uma rivalidade que pode ser explicada pelo modo como alguns, no passado, se referiam a essas comunidades: Berlim $x$ Varsóvia ${ }^{3}$. Ela explica que a autoestima dos poloneses foi sempre baixa, sempre considerados inferiores em relação aos demais, o que dificultou a manutenção da língua polonesa. (Diário de campo, 08 de fevereiro de 2014).

Contudo, quando entendemos, a partir de Silva (2000, p. 92), que o conceito de performatividade muda a ênfase na identidade como descrição "para a ideia de 'tornar-se', para uma concepção da identidade como movimento e transformação", vemos que fazer o contrário, por meio de atos de fala que se oponham a esses que buscam manter a inferioridade polonesa, também é possível. E é isso que esses projetos buscam fazer.

Isso foi possível perceber em entrevistas como a de um aluno do curso de língua polonesa, P3, sobre a visão que se tem dos descendentes de poloneses. Para ele,

${ }^{3}$ No modo como $\mathrm{se}$ referia $\mathrm{m}$ à $\mathrm{s}$ comunidades, podemos perceberque a nomeação é sócio-historicamente construída e apresenta forte influência política, pois utilizavam o nome das capitais da Alemanha e da Polônia para se referirem, respectivamente, à comunidade alemã, do centro da cidade, e à comunidade polonesa. Assim, tendo em vista os conflitos entre esses dois países, o fato de nomear essas comunidades dessa forma revela que a rivalidade também estava claramente marcada no Brasil.
A relação dos descendentes poloneses com a língua polonesa é de valorizar a cultura de seus descendentes, o uso e a importância dada à língua polonesa, despertando nas comunidades o interesse em reavivar a língua, música e as crenças. Sentindo-se encorajados, passaram a fazer o uso da língua em público o que antes não mais se ouvia, pois alguns sentiam-se constrangidos: a valorização dos descendentes divulga no Brasil a importância da Polônia no contexto mundial de descobertas científicas e a popularidade do Papa João Paulo II. (P3. Entrevista realizada em junho de 2014).

P3 acredita que, para "reavivar" a língua, é necessário que haja um encorajamento, de forma que os descendentes não se sintam constrangidos. Nesse sentido, entender a importância da Polônia no contexto mundial, principalmente na figura do Papa João Paulo II, que é visto como um dos símbolos da Igreja Católica na contemporaneidade, é vital para inverter essa relação de inferioridade. 
Essa questão pode ser vista de maneira mais direta a partir de outra intervenção que foi realizada pela igreja de Alto Paraguaçu ${ }^{4}$, em setembro de 2014. Trata-se de um ciclo de palestras coordenado por P1, cujo título é "O que a Polônia deu ao mundo". O objetivo da ação foi aproximar aqueles que se identificam com a Polônia de sua contribuição à civilização mundial, passando pela apresentação de descobertas como a das vitaminas, dos ossos artificiais, do colete à prova de balas, da lâmpada de querosene, do ônibus sanfonado, entre outras.

Nesse sentido, não podemos desconsiderar que os imigrantes poloneses eram vistos na época em que chegaram ao Brasil como emigrantes pobres, que falavam uma língua ininteligível, vindos de um país cujos intelectuais não eram conhecidos, nem suas obras literárias, nem as suas conquistas (RODYCZ, 2011). Tendo isso em vista, não há como olhar para o título do ciclo de palestras sem verificar que o que se busca é modificar o olhar da comunidade em relação à Polônia, abordando os aspectos positivos dessa cultura que, desde o princípio da imigração, é vista como inferior, fato esse que acaba(ou) por influenciar a relação que os descendentes mantêm com essa língua.

A mudança de entendimento sobre o papel da Polônia e sobre o que é ser polonês também é algo abordado pelo projeto de intercâmbio. Podemos perceber isso na fala da coordenadora do projeto de intercâmbio, P4, quando esta, ao ser questionada sobre de que modo o uso da língua polonesa é visto dentro do contexto escolar, responde:

Felizmente a língua polonesa vem tomando um lugar de destaque em todo contexto escolar. Esta cultura, que por muito tempo foi menosprezada, atualmente é respeitada pela comunidade devido à influência positiva através de sua cultura. (P4. Entrevista realizada em maio de 2014).

Apesar de a participante afirmar que a língua polonesa vem tomando um espaço de destaque em todo contexto escolar, essa resposta não pode ser tomada como um olhar que seria comum a todos os participantes. Não podemos desconsiderar

${ }^{4}$ Bairro do município em que se localiza o Núcleo Histórico tombado pelo Instituto do Patrimônio Histórico e Artístico Nacional. a perspectiva de outros participantes que já trouxemos a este trabalho, que afirmam que muitos poloneses se sentem constrangidos ao utilizar a língua polonesa e menosprezam essa cultura, além de considerar nossa própria percepção do 
contexto a partir do contato com a comunidade. De qualquer forma, a participante não nega o menosprezo pelo qual passam/passaram os poloneses. Contudo, tendo em vista as falas das participantes do projeto de intercâmbio, já é possível ver algumas mudanças nesse sentido, conforme abordaremos na sequência.

Em relação à relevância do projeto, ela afirma que

Este projeto é de extrema importância para os jovens e já vem trazendo resultados positivos, como, por exemplo, o interesse pela cultura polonesa. E tenho certeza de que esse interesse aumentará. (P4. Entrevista realizada em maio de 2014).

Essa questão da "mudança" de visão que provoca uma desestabilização também pode ser vista nas respostas de P5 e P6 à seguinte questão: “Como participante do projeto, o que você aprendeu a partir do seu envolvimento com a língua polonesa e com outra realidade?". Segundo as participantes,

A diferença entre a cultura brasileira e a cultura polonesa é grande. Aprendi a respeitar os valores de outra cultura, a valorizar, ainda mais, a cultura de nossos antepassados, e até mesmo a cultura de nossa cidade. (P5. Entrevista realizada em maio de 2014).

Apesar de nossas culturas serem um tanto parecidas aprendi que devemos respeitar outros estilos de vida, outras culturas e que vivenciar outras experiências faz a gente crescer muito em conhecimento e cultura. (P6. Entrevista realizada em maio de 2014).

Apesar de elas divergirem sobre o fato de a cultura polonesa ser ou não parecida com a cultura brasileira, diferenças e semelhanças essas que não podemos precisar a partir das respostas dadas, ambas afirmam que, com o projeto, aprenderam a respeitar outras culturas. Uma fala bastante interessante de P5 é que ela aprendeu a valorizar a cultura de seus antepassados e da própria cidade.

Podemos entender que esse projeto é uma oportunidade de oferecer outra perspectiva aos participantes sobre o que é ser polonês em Itaiópolis, entendendo que

em certo sentido, 'pedagogia' significa precisamente 'diferença': educar significa introduzir a cunha da diferença em um mundo que sem ela se limitaria a reproduzir o mesmo e o idêntico, um mundo parado, um mundo morto. É nessa possibilidade de abertura para um outro mundo que podemos pensar na pedagogia como diferença. (SILVA, 2000, p. 101). 
5 Amparados em Woodward (2000), podemos afirmar que, para a concepção essencialista, a identidade já é "dada", pode ser uma imposição construída historicamente ou mesmo justificada pela biologia, como a genética. Já a segunda se relaciona com o "tornarse", com o "vir a ser", por isso é uma concepção que dá possibilidade de se pensar em identidades fluidas, não estáveis.
Isso ganha mais dimensão quando consideramos as possibilidades do modelo virtual de interação, já que permite o contato entre pessoas que, muito provavelmente, sem as novas tecnologias, jamais poderiam estabelecer uma relação de troca.

Outro ponto que gostaríamos de abordar a partir das entrevistas é o modo como fica explícita a forte relação entre língua e identidade, a qual temos discutido. Quando questionamos sobre a visão que se tem sobre a língua polonesa, P5 afirma que

para os descendentes de poloneses, a cultura e a língua polonesa é de suma importância. É algo a ser aprendido e valorizado por todos: é a nossa identidade cultural. As demais pessoas também acham importante. Aqui em nossa cidade temos curso de língua polonesa, aulas de dança polonesa. Com isso, vemos a importância dada à cultura, algumas pessoas dão mais importância, outras menos, depende da mentalidade de cada uma. (P5. Entrevista realizada em maio de 2014, grifos nossos).

No início dessa fala, P5 se aproxima da visão otimista da P4, porém acaba por modalizar um pouco essa afirmação no final da resposta, quando diz que essa valorização varia de acordo com a pessoa. Além disso, vemos que, para a participante, a cultura e a língua polonesa devem ser aprendidas pelos descendentes, pois é a identidade cultural deles. Essa fala nos leva a pensar sobre a concepção essencialista e a concepção não essencialista de identidade e de cultura ${ }^{5}$, trazida com frequência pelos participantes. Uma ressalva a ser feita é que as falas que seguem na sequência apresentam a concepção de que já há uma visão mais positiva sobre a língua polonesa.

Além disso, é imprescindível que olhemos para o trecho em destaque nessa citação, "nossa identidade cultural", pois é uma das poucas vezes em que, durante as entrevistas, temos claramente um de nossos participantes se inserindo no grupo de descendentes de poloneses, considerando que havia sempre um jogo entre "eles" e "nós", de modo que a tendência era tratar os descendentes como "eles". Vemos, com isso, que a identidade é algo múltiplo, nem sempre (ou quase nunca) bem resolvido, pois estamos sempre em negociações, permeadas por contradições. 
Ainda em se tratando da questão da visão dos descendentes e das demais pessoas sobre a língua e a cultura polonesa, P4 responde que

é um povo que sofreu muito e que conseguiu superar, sentindo muito orgulho de suas raízes, preservando sua língua, culinária, dança, festividades, religiosidade e muita alegria que são cultivados e vividos até os dias de hoje. (P4. Entrevista realizada em maio de 2014).

Começamos a ver nesse posicionamento a questão da identidade vista como uma raiz, ou seja, uma identidade baseada na história em comum. Essa questão da identidade como raiz, algo que nos parece uma concepção fixa, tendo em vista até o que significa essa palavra, pode ser vista em outra resposta, a de P7:

Após a vinda dos primeiros imigrantes poloneses a [...] e, à medida que o tempo passa, as novas gerações, $3^{\mathrm{a}}, 4^{\mathrm{a}}, 5^{\mathrm{a}} \ldots$, se tornaram menos envolvidas com suas raízes, não querendo dizer que não haja interesse em preservar esta cultura, talvez por já se sentirem ambientados em sua nova pátria, convivendo pacificamente e admirando outras etnias.

Creio que a visão das demais pessoas é das melhores possíveis, tendo em vista a importância do Tombamento de toda comunidade a nível nacional através do IPHAN pelo valor que representa [...].

Porém, há necessidade de maior divulgação e valorização desta cultura milenar, levando em consideração o espírito de colaboração e exemplos deixados pelos que nos antecederam. (P7. Entrevista realizada em junho de 2014).

Para pensar sobre a questão da identidade, entendemos que, quando afirmamos uma identidade, podemos buscar a sua legitimação na referência a um suposto e autêntico passado (WOODWARD, 2000), principalmente um passado glorioso, como no caso de P7, que vê como indispensáveis os exemplos deixados por aqueles que a antecederam. Hall discute essa questão afirmando que

as identidades parecem invocar uma origem que residiria em um passado histórico com o qual elas continuariam a manter uma certa correspondência. Elas têm a ver, entretanto, com a questão da utilização dos recursos da história, da linguagem e da cultura para a produção não daquilo que nós somos, mas daquilo no qual nos tornamos. Têm a ver não tanto com as questões 'quem nós somos' ou 'de onde nós viemos', mas muito mais com as questões 'quem nós podemos nos 
tornar', 'como nós temos sido representados' e 'como essa representação afeta a forma como nós podemos representar a nós próprios. (HALL, 2000, p. 108)

Tendo isso em vista, bem como o modo como os projetos aqui discutidos se configuram a partir da visão de nossos participantes, podemos afirmar que, apesar de algumas falas apontarem para a busca de uma identidade essencialista, por meio da busca das raízes, os projetos são capazes de reconfigurar essa visão. Por meio dessas novas visões, dos novos contatos com poloneses e com a cultura polonesa da contemporaneidade, vão se criando novas identificações, de modo a alterar a forma como a cultura polonesa é vista no contexto da pesquisa, como algo arcaico. Assim, podemos perceber na prática o que Woodward (2000, p. 22) afirma, já que, segundo ela, "essas novas identidades podem ser desestabilizadas, mas também desestabilizadoras".

Dessa forma, vemos esses projetos - materializações de políticas linguísticas - como formas de se desestabilizar essas identidades que podem partir de uma concepção essencialista baseada no passado, na origem em comum dessa comunidade, de forma que novos arranjos possam ser feitos, não desconsiderando o passado, mas percebendo que nós o reconstruímos (WOODWARD, 2000).

\section{Considerações finais}

No início do acompanhamento do desenvolvimento dos projetos, acreditávamos que as esferas in vivo e in vitro podiam ser vistas de forma separada. Contudo, quando nos envolvemos com a comunidade, foi possível ver que essas questões não são nada simples, apresentando uma complexidade cada vez maior conforme nos aproximamos de outros olhares sobre as políticas linguísticas, tendo em vista todos os agenciamentos presentes em contextos sociolinguisticamente complexos.

Assim, conforme já dito, optamos por tratar de políticas "entre" o in vivo e o in vitro, porque pudemos perceber que o projeto de intercâmbio, que, por ser desenvolvido em uma escola estadual, nos parecia um exemplo de política in vitro, foi idealizado e é coordenado por agentes de políticas in vivo, apesar de se tratar de um espaço em que as políticas de Estado são postas em prática. Desse modo, esse projeto propicia 
práticas multilíngues ao colocar em contato falantes de duas diferentes línguas utilizando ainda uma terceira língua para se comunicar, o que acarreta novas configurações sobre a compreensão de língua e de fluência.

Para pensar se as políticas são definidas in vivo ou in vitro - sem buscar generalizar o que ocorre na comunidade, pois só tivemos acesso a alguns olhares para essas políticas -, devemos, primeiramente, entender que essas políticas não podem ser vistas como dicotômicas. Não há como dizer que todas as políticas in vivo por parte da comunidade, das famílias e da igreja agem na mesma direção, da mesma forma que não podemos afirmar que todas as políticas in vitro têm os mesmos objetivos. Tratamos aqui de perspectivas diferentes tidas por sujeitos diferentes. Assim, percebemos que, mesmo sabendo que as políticas definidas nas diferentes esferas podem ser conflituosas (CALVET, 2007), devemos sempre ter em mente que, muitas vezes, são as próprias políticas in vivo que dão sustentação para as políticas in vitro de monolinguismo.

Os agentes de políticas linguísticas também devem ser vistos como aqueles que, mesmo pertencendo à esfera das políticas in vivo e a comunidades minoritárias, podem agir em prol dessa estrutura que tolhe a autonomia daqueles que buscam fazer uso das suas línguas, como as línguas de imigração, agindo segundo o ideal de "Um povo, uma língua, uma nação".

A questão da língua é vista como fortemente relacionada à identidade cultural do grupo de descendentes de imigrantes, fato este que explica o porquê de haver pessoas bastante engajadas em políticas de manutenção do uso da língua polonesa. Contudo, devemos lembrar que há aquelas que, sendo descendentes, querem marcar um distanciamento de traços que ressaltem esse vínculo, já que pode haver estigmatização.

Concluímos, amparados em Altenhofen (2013), que a maioria, entendida nem sempre como aquela parcela formada por mais da metade da população, mas sim como aquela com maior prestígio, deve ser alvo de políticas linguísticas, a fim de que sejam desenvolvidas competências plurilíngues e de que se possa "dar ouvidos" à diversidade linguística e cultural. Dessa forma, reiteramos a fala do autor supracitado quando este afirma acreditar que promover na população monolíngue uma consciência plurilíngue é tão importante quanto defender o direito das comunidades que fazem uso de outras línguas e 
de outras variedades de determinada língua. Essa perspectiva de "dar ouvidos" trazida por Altenhofen é explicada por ele da seguinte forma:

uma política linguística plural implica a inclusão e o respeito à diversidade de línguas, não apenas no sentido de 'garantir voz' às diferentes comunidades linguísticas que co-habitam determinado espaço de legislação, como também, e, principalmente, no sentido de 'dar ouvidos' e incentivar o plurilinguismo como postura adequada para uma 'democracia cultural'(ALTENHOFEN, 2013, p. 96).

Vemos, por isso, que o fato de as ações motivadas por políticas linguísticas que buscam a manutenção do uso da língua ficarem alheias ao que acontece no ambiente escolar e não agirem nesse espaço pode fazer com que não se consiga um bom resultado, uma vez que, mesmo que não haja apenas descendentes de poloneses ou de outra origem étnica, é necessário que o trabalho com a língua seja feito.

Podemos, então, perceber serem necessários trabalhos no sentido de políticas para a maioria, pois o futuro da língua, o modo como os falantes e as próximas gerações se relacionarão com ela, tem muito a ver com o que a maioria linguística, falante de uma variedade prestigiada de língua portuguesa, diz sobre a língua polonesa e o modo polonês de usar a língua portuguesa. Dessa forma, a partir da não negação das relações que podem ser estabelecidas entre língua, cultura, identidade e religião na comunidade de Itaiópolis, é possível pensar em políticas linguísticas respeitando as diversas posições sobre esses temas que quase sempre são divergentes.

\section{REFERÊNCIAS}

ALTENHOFEN, Cléo V. Bases para uma política linguística das línguas minoritárias no Brasil. In: NICOLAIDES, Christiane; SILVA, Kleber Aparecido da; TÍLIO, Rogério; ROCHA, Claudia Hilsdorf. Política e Políticas Linguísticas. Campinas: Pontes Editores, 2013. p. 93-116.

; MARGOTTI, Felício Wessling. O português de contato e o contato com as línguas de imigração no Brasil. In: MELLO, Heliana; RASO, Tommaso; ALTENHOFEN, Cléo (Orgs.). Os contatos linguísticos no Brasil. Belo Horizonte: Editora UFMG, 2011. p. 289-315. 
Política linguística, mitos e concepções linguísticas em áreas bilíngues de imigrantes (alemães) no Sul do Brasil. Revista Internacional de Linguística Iberoamericana (RILI). Frankfurt a. M., v. 1, n. 3, p. 83-93, 2004.

ANDERSON, Benedict. Comunidades Imaginadas. São Paulo: Companhia das Letras, 2008.

CALVET, Louis-Jean. As politicas linguísticas. São Paulo: Parábola: IPOL, 2007.

CAVALCANTI, Marilda C. Estudos sobre Educação Bilíngue e Escolarização em Contextos de Minorias Linguísticas no Brasil. DELTA. n. 15, p. 385-418, 1999.

HALL, Stuart. Quem precisa de identidade? In: SILVA, Tomaz Tadeu. (Org.) Identidade e Diferença: a perspectiva dos Estudos Culturais. Petrópolis: Vozes, 2000. p. 103-133.

MAHER, Terezinha Machado. Ecos de resistência: políticas linguísticas e línguas minoritárias no Brasil. In: NICOLAIDES, Christiane; SILVA, Kleber Aparecido da; TÍLIO, Rogério; ROCHA, Claudia Hilsdorf. Politica e Políticas Linguísticas. Campinas: Pontes Editores, 2013. p. 117-134.

OLIVEIRA, Gilvan Müller; ALTENHOFEN, Cléo V. O in vitro e o in vivo na política da diversidade linguística do Brasil. In: MELLO, Heliana; RASO, Tommaso; ALTENHOFEN, Cléo (Orgs.). Os contatos linguísticos no Brasil. Belo Horizonte: Editora UFMG, 2011. p. 187-216.

Política Linguística na e para além da Educação Formal. Estudos Linguísticos XXXIV, p. 87-94, 2005, p. 87-94.

. (Org.) Declaração universal dos direitos linguísticos: novas perspectivas em política linguística. Campinas: Mercado de Letras, 2003.

PINTO, Joana Plaza. Modernidade e diferença colonial nos discursos hegemônicos sobre língua no Brasil. Muitas vozes. Ponta Grossa, v.1, n.2, p. 171-180, 2012.

RAJAGOPALAN, Kanavillil. A geopolítica da língua inglesa e seus reflexos no Brasil: por uma política prudente e propositiva. In: LACOSTE, Yves (Org.). A Geopolítica do Inglês. São Paulo - SP: Parábola, 2005, p. 135-159. 
Política Linguística: do que é que se trata, afinal? In: NICOLAIDES, Christiane; SILVA, Kleber Aparecido da; TÍLIO, Rogério; ROCHA, Claudia Hilsdorf (Orgs.) Política e Políticas Linguísticas. Campinas: Pontes Editores, 2013. p. 19- 42.

RODYCZ, Wilson Carlos. Os imigrantes poloneses da Colônia Lucena - Itaiópolis: se um marreco pisar no gelo ele quebra. Porto Alegre: Rodycz \& Ordakowski Editores, 2011.

SIGNORINI, Inês. Política, Língua Portuguesa e Globalização. In: MOITA LOPES, L. P. Português no Século XXI: cenário geopolítico e sociolinguístico. São Paulo: Parábola, 2013. p. 74-100.

SILVA, Tomaz Tadeu. A produção social da identidade e da diferença. In: SILVA, Tomaz Tadeu (Org.) Identidade e diferença: a perspectiva dos estudos culturais. Petrópolis: Vozes, 2000. p. 73-102.

WACHOWICZ, Ruy Cristovam. As escolas de colonização polonesa no Brasil. Curitiba: Champagnat, 2002.

O camponês polonês no Brasil. Curitiba: Fundação Cultural Casa Romário Martins, 1981.

WOODWARD, Kathryn. Identidade e diferença: uma introdução teórica e conceitual. In: SILVA, Tomaz Tadeu (Org.) Identidade e diferença: a perspectiva dos estudos culturais. Petrópolis: Vozes, 2000. p. 7-72. 


\section{Abstract \\ Language policies in the city of Itaiópolis-SC: relations between language and identity}

This article proposes a discussion on language policies related to the maintenance of the use of Polish immigration language in Itaiópolis - Santa Catarina, which had meant immigration of this ethnic group in order to discuss the relationship between language policies in vivo and in vitro (CALVET, 2007), and the relationship that can be established between language and identity. For this, views of community members, taken in this research as language policies agents, are presented. We emphasize that the majority of participants is linked to any project aimed at the maintenance of language and immigration culture, among which we highlight two projects, the first is a Catholic Church's project that aims to offer Polish lessons for the community and the second is developed at a state school which aims to provide opportunities for students to get in touch with the language and Polish culture through contact with native speakers of Poland. As a result, we emphasize that it was revealed that the spheres of in vivo administration and in vitro relate quite markedly. In addition, in relation to the identity issue, we realize that this can be considered the main force behind these agents of language policies.

Keywords: Identity. Language policies. Polish language. 